\title{
STRATEGY MANAGEMENT IN OVERCOMING RELIGION CONFLICTS IN PLURAL COMMUNITIES IN MOPUYA SELATAN VILLAGE, BOLAANG MONGONDOW DISTRICT
}

\author{
Dian Adi Perdana ${ }^{1 *}$, Budi Nurhamidin ${ }^{2}$ \\ ${ }^{1}$ Institut Agama Islam Negeri Sultan Amai Gorontalo, Indonesia, e-mail: dianadiperdana@,iaingorontalo.ac.id \\ ${ }^{2}$ IAI Muhammadiyah Kotamobagu, Gorontalo, Indonesia, e-mail: budinurbamidin13@gmail.com \\ *Corresponding Authors \\ (c) (1) (-) \\ (C)2021 by the authors. Submitted for possible open access publication under the terms and conditions of the Creative Commons \\ Attribution-ShareAlike 4.0 International License-(CC-BY-SA) (https://creativecommons.org/licenses/by-sa/4.0/)

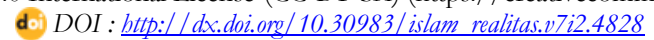 \\ \begin{tabular}{l|l|l} 
Submission: 28 September 2021 & Revised: 2 December 2021 & Published: 31 December 2021
\end{tabular}
}

\begin{abstract}
This research aims to discuss the pluralism in heterogeneous region that focuses on three communities of different religions living side by side in harmony and peace. The Plural community develops in South Mopuya Village makes the prevention of conflict needs to be improved.. Researcher discusses how the strategies of religious leaders does and government give understanding to Mopuya's society to avoid and prevent conflict in plural society. This research is using qualitative method. The data are gained by using some techniques such as observation, interviews, and documentation. Data obtained will be analyzed using qualitative descriptive analysis. Plurality in this study, assimilation of activities, Need each other at work and increasing awareness of the importance of education, tabligh da'wab and worship tolerance are strategies to prevent conflict. Persuasive approach and language equality as unifying solution for a plural society to live in harmony and peace.
\end{abstract}

Keywords: Management of strategy, Conflict of religion, Plural

\begin{abstract}
Abstrak
Masyarakat Plural berkembang di Desa Mopuya Selatan menjadikan pencegahan konflik antar umat beragama perlu ditingkatkan. Peneliti akan mengkaji pluralisme di wilayah heterogen yang terfokus pada keagamaan dengan tiga komunitas penganut agama yang berbeda bidup berdampingan dengan rukun dan damai. Penelitian ini mengkaji bagaimana strategi tokoh agama dan pemerintah dalam memberikan pemahaman kepada umatnya untuk. menghindari dan mencegah konflik pada masyarakat plural dan bagaimana tantangan serta solusi tokoh lintas agama dalam mengatasi konflik, pada masyarakat plural. Penelitian ini merupakan penelitian kualitatif dengan teknik, pengumpulan data observasi, wawancara dan dokumentasi Data yang diperoleh akan dianalisis menggunakan analisis deskriptif kualitatif. Pluralitas dalam studi ini, asimilasi kegiatan, saling membutubkan dalam pekerjaan dan meningkatkan kesadaran akan pentingnya pendidikan, dakwah tabligh dan toleransi ibadah menjadi strategi mencegah konflik. Pendekatan persuasif dan penyetaraan bahasa sebagai solusi pemersatu masyarakat plural untuk bidup rukun dan damai.
\end{abstract}

Kata Kunci: Manajemen strategi, Konflik agama, Plural

\section{Background}

Indonesia is a country that has a multicultural culture, both in terms of religion, ethnicity, language, and culture. ${ }^{1}$ Pluralism in Indonesia is not a new phenomenon, at least during the New Order era, this idea ever to

discuss the government's official agenda in order to create the life harmony of religious people in Indonesia. ${ }^{2}$ Discourse of pluralism made by the government not only aiming to maintain harmony so that the integrity of the

${ }^{1}$ Erwin Jusuf Thaib, "Dakwah dalam Perspektif Pluralitas (Studi Analis SWOT pada Masyarakat Kota Gorontalo)" (UIN Alauddin Makassar, 2016), p. 21

2 Arfan Nusi, Mengaji Pluralisme Agama Kepada Nurcholish Madjid (Yogyakarta: Atap Buku, 2015), 12. 
Indonesian state do not broke, it is only a matter of differences in beliefs, ideology, culture, language and so on.

The social facts above are the main concepts in seeing the social reality that exists in Indonesia. Social facts defined as something that generally covers the whole of society both law, morals, beliefs, habits applied in the community to contain general needs of social orgasm. ${ }^{3}$ Social functions in a social fact must be fulfilled as a means of the life needs of the nation and state. This fact is actually inseparable from the plurality of the Indonesian nation which consists of various elements of the nation that are not the same.

In a multicultural society, certainly we can see the differences in society. These differences can form anywhere, because each difference creates its own habitat. ${ }^{4}$ Because it is caused by several factors, such as geographical conditions, it can be a very big factor affecting the creation of the plurality of Indonesian ethnic groups. ${ }^{5}$ Religious differences do not need to be conflicts when each of them deeply understands their religious teachings. Religious communities to the characteristics and views of religious life held by religious groups respect each other. ${ }^{6}$ Differences religion, ethnicity and culture do not be surprised if there is a potential for conflict that will be born, due to disagreements and the nature of group fanaticism and the differences in interests to dispute between religions, ethnicities and cultures. Problems related to religion are everyone's personal

\footnotetext{
${ }^{3}$ Ramdani Wahyu, Imu Sosial Dasar (Bandung: CV. Pustaka Setia, 2017)

4 Ahmad Zaenuri, Mengawal Peradaban (Sebuah Pemikiran Seputar Pluralisme, Pendidikan, Sosial, dan Budaya) (Yogyakarta: Trussmedia Grafika, 2015)

5 Thaib, "Dakwah dalam Perspektif Pluralitas (Studi Analis SWOT pada Masyarakat Kota Gorontalo)."

${ }^{6}$ Hamdan Daulay dan Andy Dermawan, Dakwah di Tengah Persoalan Budaya dan Politik (Yogyakarta: LESFI, 2001)

7 Zaenuri, Mengawal Peradaban (Sebuah Pemikiran Seputar Pluralisme, Pendidikan, Sosial, dan Budaya).
}

domain, ${ }^{7}$ This social fact described in abstract social phenomena's, such as law, customs, norms, language, religion and other of life which is certain powers to force that power manifests in people's lives beyond the ability of individuals. $^{8}$

Community life will not avoid a conflict, but the conflict has a trigger, this trigger can be prevented as early as possible. Kornblurn said that conflict is the phenomenon that's most often arises because conflict was always been a part of social and political human and can be driver a force in socio-political dynamics and changes. ${ }^{9}$ Religious conflicts can be occurred because of cyberbullying and hate posts that are communicated as issues of religious differences, this is which media literacy needed to prevent conflict and prepare young generations to be wise and critical to encounter conflicts which it can arise at any time. ${ }^{10}$ Conflict management needed personally or interpersonally, because conflict created by a person or group who makes constructive or destructive changes, therefore conflict management needs to use conflict strategies and conflict tactics. ${ }^{11}$

Conflict management needs to be applied to every individual and group activity when it occurred or has not done, because prevention efforts needed to increase a human awareness for the importance of peace. Conflicts between groups, usually start from unresolved individual problems and then developing to become conflicts between groups. Conflicts can be also occurred in the internal group caused by

\footnotetext{
8 Dadang Kahmad, Sosiologi Agama (Bandung: Remaja Rosdakarya, 2000)

9 Hendrik Risman, "Upaya Pemerintah Daerah Kabupaten Kutai Barat dalam Menyelesaikan Konflik Tapal Batas Antar Kampung di Daerah Kabupaten Kutai Barat (Konflik Kampung Muhur dan Kampung Kaliq),' EJournal Pemerintahan Integratif 3, no. 3 (2015): 393.

10 Anisa Setya Arifina, "Literasi Media Sebagai Manajemen Konflik Keagamaan di Indonesia," Jurnal Komunikasi dan Kajian Media 1, no. 1 (2017): 54.

11 Hasan Waduloh, "Manajemen Konflik dalam Perspektif Dakwah," Jurnal Dakwah Tabligh 15, no. 1 (2014): 103.
} 
unequal perceptions, goals or targets. ${ }^{12}$ Conflict management is the ability to control conflicts to be occurred, which it requires management skills. If in Islam, conflict is not as a goal but as a means to unite various conflicting things to free human life from individual interests and ugliness so that then they can be brought to the right path. ${ }^{13}$

Wasisto said that there was a strategy to minimize conflict which was resolved with a local wisdom approach, namely promoting community cohesiveness in the reconciliation process, starting with balanced bureaucratic representation in maintaining peace. ${ }^{14}$ Yohanes said that the existence of traditional institutions is very important in reducing conflicts in the form of deliberation which must be carried out regularly as an effort to prevent conflicts that will occur. If there is a conflict, deliberation must also be carried out immediately to stop the prolonged conflict. ${ }^{15}$ Pluralism always continues to be grounded in the Indonesian people to prevent and avoid conflicts between groups for any reason. Ideally, conflicts can be triggered by various things, from small to large things. The existence of the introduction of the values of pluralism makes people respect, love and do not disagree with each other. Conditions can be arose from incompatibility that affecting various parties will become to conflict, which will result in endangering institutional instability, dynamic stability in the organization that can lead to progress or setbacks. ${ }^{16}$ Religious diversity is completely freedom for humans, because Islam does not deny existing religions

12 Faiz Karim Fatkhulah Valentina Purnama Dewi, Sugeng Suwagi, Udin Sumarsah, Sofyan Sauri, "Penerapan Manajemen Konflik Berbasis Agama dan Psikologi Studi Kasus di SMK Negeri 29 Jakarta," Eduvis : Jurnal Manajemen Pendidikan Islam 6, no. 2 (2021): 127.

13 Indah Muliati, "Manajemen Konflik dalam Pendidikan Menurut Perspektif Islam," Tingkap: Jurnal Ilmiah Ilmu-Ilmu Sosial Budaya \& Ekonomi 12, no. 1 (2016): 50.

14 Wasisto Raharjo Jati, "Kearifan Lokal Sebagai Resulosi Konflik Keagamaan,” Jurnal Walisongo 21, no. 2 (2013): 393-416. and Islam recognizes the existence of other religions and it does not reject the values of their teachings.

Pluralism teaches every human being to respect the other's religions and beliefs, because this world consists of a pluralistic society. Umi Hanik said to create harmony in life and pluralism, there needs to be openness or transparency, being aware of differences, being critical, having similarities and having a willingness to understand religious beliefs, rites and symbols for understanding others properly. ${ }^{17}$ From the previous studies above, pluralism needs to be disseminated for human peace. Researcher will discuss pluralism in a heterogeneous area which it focused on religion community in Mopuya Selatan Village, Dumoga Utara District, Bolaang Mongondow Regency which three communities of different religions can live side by side in harmony and peace. This study discuss about how do the strategies of religious leaders and the government that giving understanding to their society to avoid and prevent conflict in a plural society and how do the challenges and solutions of interfaith leaders in overcoming conflicts in a plural society, so that this research expected to contribute to the study of pluralism.

This research is a field research which it use a qualitative approach. The data obtained from direct observation, interviews and documentation. There are six informants in this study, three of them are religious leaders from each religion, one village government person is the main informant in this study and two others

15 Yohanes Bahari, "Model Komunikasi Lintas Budaya dalam Meresolusi Konflik Berbasis Pranata Adat Melayu dan Madura di Kalimantan Barat," Jurnal Ilmu Komunikasi 6, no. 1 (2008): 1-12.

16 Yusnia Binti Kholifah, "Manajemen Konflik Perspektif Pendidikan Islam," Piwulang: Jurnal Pendidikan Agama Islam 2, no. 1 (2019): 23.

17 Umi Hanik, "Pluralisme Agama di Indonesia," Tribakti: Jurnal Pemikiran Keislaman 25, no. 1 (2014): 61. 
are supporting informants. This research focused on phenomenon in the object of research which is supported by documentation obtained from the object of study. The data obtained will be studied, analyzed and interpreted to make it easier to draw conclusions from the phenomenon found on object. Then, researcher provide the results from the previous questions. ${ }^{18}$

The data obtained will be analyzed using descriptive qualitative analysis, it describe the actual information obtained on object, especially related to the strategies of each religious and government figure in overcoming conflict in a plural society and supported by several literatures to complete the discussion of the studies observed, researched and analyzed. The using of literature as a way for researchers to explain a phenomenon, to look for the relationship of phenomenon, the relationship interpreted with the ideas of researcher which comes from the literature. ${ }^{19}$ So that, the results obtained from various information can support this research and can be a reference for the next researchers in the same field.

\section{Mopuya Selatan Village: Description and History}

The harmony that has been creating in the village of Mopuya, certainly has a very basic factor, which is related to the history of the formation of this village. It recorded from 1972 to 1974, the Government through the Department of Transmigration for the North Sulawesi region, Mr. Muhibagani pioneered the clearing of wilderness for housing as many as 100 trans migrant, and brought in 2,672 trans migrants or 500 families from Java Island and Bali Island. The trans migrants get a guarantee of life for 1 year in the form of basic groceries and land for housing and cultivation of 2 hectares per family, which is still a wilderness.

18 Sandu Siyoto and M. Ali Sodik, Dasar Metedologi Penelitian, Dasar Metedologi Penelitian, 2018.
The first house of worship established by using the regional office of trans migrants' logistics warehouse grocery. The trans migrants worked together to clean the warehouse. On Fridays, it is used for Friday prayers of Muslims and Sundays it is used for worship places of Christians.

In 1963, Balinese arrived after the eruption of Mount Agung and they spread in several villages including Mopuya. In 1973, based on the idea of the regional office of transmigration, places of worship for trans migrants began to build it. Each religion gets $2,500 \mathrm{~m}^{2}$, for Islam added $2,500 \mathrm{~m}^{2}$ to build madrasah. Now, there are 6 houses of worship, namely the Mosque of Jami' Al-Muhajirin, GMIM members of the PGI Congregation Imanuel Mopuya, Puseh Temple for Hindus, KPGM Church for the Mopuya Calvary Session, Catholic Church of St. Yusuf Mopuya, and Pentecostal Church. Mosque of Jami' AlMuhajirin, GMIM members of the PGI Congregation Imanuel Mopuya and Puseh Temple for Hindus side by side with the boundary wall of the fence.

Based on the data contained in the Mopuya Selatan Village Government, in 1980, Mopuya Village became the definitive village and the next year the Mopuya community was first charged with paying land taxes and PAD. Since 1984 to 2011, Mopuya Village developed into 5 villages consist of Mopuya Selatan Village as the main village and Mopuya Utara Village, Mopuya Selatan Satu Village and Mopuya Selatan Dua Village as a division village. The explanation of history of Mopuya Village above, that this village is a transmigrant village, a heterogeneous village, a village inhabited by various ethnics and religions.

19 Ismail Nurdin dan Sri Hartati, Metodologi Penelitian Sosial (Surabaya: Media Sahabat Cendekia, 2019), p. 23. 


\section{Interfaith Leaders, Conflict and Plural Society Mopuya}

The term Plurality is often interpreted as a pluralistic community situation, especially related to social and political problems. In relation to religion, this term understood as a different religion in a society. As an understanding of diversity, true multiculturalism is a continuation of pluralism. As a continuation of pluralism, multiculturalism seeks to emphasize in addition to developing thoughts about pluralism which, among others, recognize the existence of a common platform between cultures and diverse beliefs, while also recognizing aspects that cannot be compromised. Nurcholish Madjid in Shofan said recognition of common platforms that talk about teachings to other religious groups to find a common thread or kalimatun sawa' as the basis for establishing dialogue and social cooperation. ${ }^{20}$

Structural differentiation in society can also cause problems, ${ }^{21}$ but in every problem that occurs there must be a solution to resolve the conflicts that occur. This method includes changes in the structure of the coordination mechanism in conflict resolution, the very important thing is that it is important to listen actively to the complaints of the parties to the conflict to ensure that the conflict needs to be communicated in its resolution, then reformulate the problem that is the source of the conflict to be able to find a common ground for the problem. ${ }^{22}$

The condition of people who are polarized into ethnic, religious and cultural groups, the understanding that must always be given is that all religions always teach about

20 Moh. Shofan, "Pluralisme Agama Bukan Nihilisme: Respon untuk Kaum Fundamentalis," Konfrontasi: Jurnal Kultural, Ekonomi dan Perubahan Sosial 3, no. 1 (2016): 10.

21 Nanang Martono, Sosiologi Perubahan Sosial (Depok: RajaGrafindo Persada, 2011), 12.

22 Usman Effendi, Asas Manajemen (Jakarta: Rajawali Press, 2014). goodness and peace in social life regardless of what religion of community, so that the goals of every religion can be achieved. Based on the results of research that researchers have obtained at the research location through informants that so far in the village of Mopuya Selatan there have never been conflicts related to syara'. This village is also ranked first as a region of harmony awareness in North Sulawesi.

The statement of the informant said that Mopuya Selatan Village is an area that is aware of interfaith harmony that produces the region as the number one region of harmony in North Sulawesi. The diversity of the area and high tolerance needs to be fostered so that peace can be maintained. We can do to safeguard all of that, it is necessary to have an organization that can overshadow all religions and schools or education that provides an understanding of tolerance among religious people. ${ }^{23}$ The religions embraced by Indonesian society basically have passed the selection stage that the religion provides good teaching to its people. The belief in the absolute truth of the teachings of God in His revelations from adherents of all religions cannot be sued. ${ }^{24}$ Each religion also teaches tolerance of religious life by respecting and respecting one religion with another religion.

The explanation of informants, we can be understood that the teachings taught by any religion always emphasize the values of goodness in establishing social relations between people to achieve the ultimate life in the world and the hereafter. Because in the life of the community built is a good social relationship hablumminannas to make a safe and

23 Kuswandi Gali, (Village Head of Mopuya Selatan Village) Interview, \{Tuesday, 16 th April 2019\}

24 Abdul Munir Mulkhan, Teologi Kiri, Landasan Gerakan Membela Kaum Mustadi'atin (Yogyakarta: Kreasi Wacana, 2002), 12. 
peaceful area. Unlike the case with religious activities related to beliefs, we cannot mix this matter, because every religion has a way for worship his God. But when we look at it from a social standpoint, we must respect and respect each other with the aim of maintaining harmonious relations between the communities so that they are not divided just by mutual understanding that my religion is the most correct and their religion is wrong. As preachers and promoters as well as movers certainly have a very important task to change the attitudes and behavior of humans so that they understand each other regardless of ethnicity, culture and religion. ${ }^{25}$

In the order of social life there needs to be mutual respect for each other in order to be able to establish a harmonious and peaceful life like what is the ideals of the Indonesian people themselves. Pluralism discourse in Indonesia is a very good discourse because it is in accordance with diversity and the diversity of the Indonesian people themselves who are wrapped in a unity framework that is "Bhineka Tunggal Ika" is different but still one. Talking about the problem of anticipating conflicts between religious communities is very important the role of religious leaders and the government for how to always think to maintain harmony and work to provide understanding to the community or the congregation to always live in harmony and peace, in accordance with the basic state stated in the Third Precepts namely "Persatuan Indonesia". The contents of the Third Principle contain meaning that the community is always united and appropriate for the integrity of this nation.

25 H. Imam Sujai, (Leader of Hindu) Interview, \{Wednesday, 17 th April 2019\}; Barent Suahani, (Leader of Christ) Interview, \{Thursday, 18 th April 2019\}; and I Wayan Sutaman, (Leader of Hindu) Interview, \{Friday, 19 th Apil 2019\}

26 Kuswandi Gali, (Village Head of Mopuya Selatan Village) Interview, \{Tuesday, 16 th April 2019\}

\section{The Government and Plural Society Mopuya}

Mr. Evert Erenst Mangindaan, who was then serving as Governor of the Province of North Sulawesi, gave birth to the motto is "Torang Samua Basudara" which was then continued by Governor Olly Dondokambey he issued a motto "Torang samua Ciptaan Tuhan". ${ }^{26}$ This illustrates that the government wants to provide understanding through the motto for the community to maintain security and peace in social life, even though we live in a pluralistic area in terms of religion, ethnicity and culture. The aspects of social life with the existence of plurality markers in overcoming conflicts in the community of Mopuya Selatan Village government which are implemented by the government are as follows:

\section{Assimulation of Activities}

Assimilation is a social process characterized by differences cultures or differences traditions, living at the same time and the same place, and unification of cultures. ${ }^{27}$ M. Blau, one of the originators of the theory of exchange, said that exchange can be seen from anywhere. The main idea of Blau is the interaction that occurs between individuals or groups that occurs in human life based on the expectation of reciprocating reactions from other parties. Instead, the interaction will stop if the expected reaction does not come. Social exchange will continue as long as the "gift" given by one person will be returned by others. ${ }^{28}$ Assimilation of this activity needs to be done by the government to involve the whole community regardless of ethnicity or religion so

27 Iwan Ramadhan, Agus Sastrawan Noor, and Supriadi, "Asimilasi Perkawinan Arab-Melayu Kampung Arab Kelurahan dalam Bugis Pontianak," Khatulistiwa: Jurnal Pendidikan dan Pembelajaran 4, no. 4 (2015): 2.

${ }^{28}$ Esty Setyarsih, "Fenomena Makelar Kost dalam Sudut Pandang Sosio Ekonomi Ditinjau dari Teori Pertukaran Peter Michael Blau," Jurnal Analisa Sosiologi 6, no. 2 (2017): 86 
that a good and harmonious sense of family can be established.

Explanation of the informant says how the role of government to be able to increase the sense of kinship through the assimilation of activities carried out by the government to create a sense of mutual cooperation that is to involve each other in each activity. This understanding gives color to the aspects of community life in Mopuya Selatan Village with high social value. With a pluralistic picture of society in terms of religion and ethnicity, the strategy that must be applied by the government of Mopuya Selatan Village must be general without touching the faith of every religious community. Conditions like those described above demand a persuasive approach that must be applied by the government to its people. ${ }^{29}$

\section{Need each other at work}

The basics of social interaction in sociology stems from Max Weber's thinking about social action. This idea is a new concept that is different from previous sociological thoughts such as Durheim who sparked that the main study of sociology lies in social facts. For Weber, social structure and social institutions (as social facts) help to shape human actions that are full of meaning. ${ }^{30}$

In today's era there are many issues relating to sara caused by irresponsible individuals who only think of personal interests without seeing the effects of what they do. With this equality of workers, the people of Mopuya Selatan Village are not easily provoked by sara issues, even though Mopuya Selatan Village is a plural village of Religion and Ethnicity, this is a supporting factor for the community to live in

29 Kuswandi Gali, (Village Head of Mopuya Selatan Village) Interview, \{Tuesday, 16 th April 2019\}

30 Sitti Hardiyanti and Idham Irwansyah, "FaktorFaktor Yang Mempengaruhi Penggunaan Kontrasepsi dan Hak Reproduksi Perempuan pada Keluarga Akseptor KB di Kelurahan Maccorawalie Kab. Pinrang," Predestination: Journal of Society and Culture 1, no. 2 (2021): 97. harmony and peace. With the equality of work and the people of Mopuya Selatan Village, they always mingle when they meet at work, this is where a sense of kinship between fellow communities can be established.

The explanation of the informants, social structure and social institutions (as social facts) help to shape human actions that are full of meaning and meaning. Their involvement in the work is very supportive in maintaining interfaith harmony. With the busyness that is owned by every society will be able to minimize the separatist actions that occur in this country. Involvement and mutual need in social activities or work proves to be able to create and improve a good and peaceful level of social life. The people of Mopuya Selatan Village provide an illustration for us to think more productively, not get caught up in conflicts related to sara, as is developing in our country today.

Awareness of the importance of Education

Education as an effort to pass down values that will be a helper and determinant in life as well as to improve the fate and human civilization and the giving of the basics and outlook on life to a growing generation. ${ }^{31}$ Education is a factor that greatly influences the stability of social life, therefore education must include human growth in all aspects namely spiritual, intellectual, imaginative, physical, scientific, language, both individually and collectively, and encourage all these aspects towards the good to achieve perfection. ${ }^{32}$

The informant says that disclosed above shows that the importance of education for the community for national and state life. With the awareness of the importance of education will

31 Ida Windi Wahyuni, "Penerapan Nilai-Nilai Moral Pada Santri TPQ Al-Khumaier Pekanbaru," Generasi Emas: Iurnal Pendidikan Islam Anak Usia Dini 1, no. 1 (2018): 51.

32 Azzumardi Azra, Pendidikan Islam Tradisi dan Modernisasi Menuju Milenium Baru, Wacana Ilmu: Jakarta, 1999. 
have a good effect on the order of community life in the sense that the community will be able to understand and digest what will be spook by community leaders. With the existence of a picture of a community that is aware of the importance of education, it will take into account the reality or level of awareness of not conflicting among people. Conditions like this require a role from the government and the community to motivate the next generation to get the highest level of education. ${ }^{33}$

Thus the demands in the field of education are very important in order to be able to provide understanding to the community, so that what is spook by the missionaries can be understood and digested properly and can maintain harmony between religious communities.

\section{Religious Leaders and Plural Society Mopuya}

The times are so fast, the values of da'wah must continue to be upgraded in other words religious leaders must be able to position themselves when preaching, especially when doing da'wah among a plural society. In history the development of management science has been influenced by religion, tradition, customs, and social culture. ${ }^{34}$ One variant of plurality related to social diversity is multiculturalism. As a new paradigm in da'wah there are at least four approaches to preaching multiculturalism of da'wah, namely da'wah thinking based on multiculturalism is different from conventional da'wah thinking which places faith conversion as the core of da'wah, multicultural da'wah initiated the idea of equal rights of citizens, including the rights of minority groups, da'wah based on

33 Kuswandi Gali, (Village Head of Mopuya Selatan Village) Interview, \{Tuesday, 16 th April 2019\}

34 M. Munir dan Wahyu Ilahi, Manajemen Dakwah (Jakarta: Kencana Prenada Media, 2006).

35 Hamdani Khaerul Fikri dan Danu Wiradaningrat, "Strategi dan Solusi Dakwah Pada Masyarakat Multikultural," Mudabbir: Jurnal Manajemen Dakwah 1, no. 2 (2020): 143-44. multiculturalism chooses a cultural approach that puts forward a strategy of socializing Islam as an integral part of the Ummah, and not something foreign through the development of the idea of Islam as a moral system and multiculturalism da'wah initiated the idea of intercultural and religious dialogue. ${ }^{35}$

In spreading da'wah and providing understanding of the basic things that must be possessed by religious leaders namely competence or ability and ability so that he is able to work, explain and carry out his duties as well as possible, ${ }^{36}$ in order to create a harmonious society, because society has a very significant role in carrying out the educational process for each individual. ${ }^{37}$ With this process religious leaders not only require a variety of strengths and provisions but also from a personality development that is open and has a high commitment in his capacity as an element of a religious figure, so that he is able to transcend the boundaries of primordialism but still stands above his intellectual capacity, because preaching is basically identical to the value of the struggle itself. ${ }^{38}$ The aspects of da'wah applied by religious leaders to the plural society in Mopuya Selatan Village, so that worship and muamalah activities can continue without causing offense or disturbance between religious communities, namely there are two methods of preaching as follows:

\section{Dakwah Tabligh}

Tabligh an important part of da'wah. However, tabligh is a process of delivering religious teachings, because tabligh is an integral part that is impossible to surpass, therefore preaching with a wide scope of arable work, it is

36 A. Ilyas Ismail dan Prio Hotman, Filsafat Dakwah, Rekayasa Menbangun Agama dan Peradaban Islam (Jakarta: Kencana Prenada Media, 2011).

37 Pimpinan Pusat Muhammadiyah, Berita Resmi Muhammadiyah.

${ }^{38}$ Hasanatul Jannah, "Kyai, Perubahan Sosial dan Dinamika Politik Kekuasaan," Fikrah - Jurnal Ilmu Aqidah dan Studi Keagamaan 3, no. 1 (2015): 173. 
not possible to do without tabligh. ${ }^{39}$ Tabligh is an activity to convey religious teachings to the public so that the community or worshipers can apply in everyday life, carry out what is ordered and stay away from what is forbidden in order to achieve the pleasure and harmony in accordance with what is expected by every joint of human life.

Community development interpreted as an effort to build the community from all its aspects gradually and regularly leading to desire direction or goals. If this understanding is associated with propaganda as socialization, then at least two mutualism relations are found.$^{40}$ First, in terms of the objectives of the da'wah community development have links that strengthen one another. Second, da'wab in terms of methods and approaches, da'wah and community development have complementary relationships. Building a community is not enough to only one aspect by forgetting the other aspects. Moreover, Human development must be comprehensive in terms of humanity, so that it becomes a perfect creature according to its degree as a human being. ${ }^{41}$

The statements of the informants that they say, we can be understood that in the village of Mopuya Selatan, awareness of giving advice to the congregation has been well formed, despite the absence of an intense meeting of religious leaders who talk about religious harmony, the religious leaders in the village of Mopuya Selatan have been able to describe their awareness to always be the pioneers of matters relating to existing social dynamics. ${ }^{42}$

39 Asna Istya Marwantika, "Pemetaan Aliran Pemikiran Dakwah Ditinjau dari Periodisasi Gerakan Dakwah dan Konsep Keilmuan," Qalamuna: Jurnal Pendidikan, Sosial dan Agama 7, no. 1 (2015): 5.

40 Windy Novita, Kamus Ilmiah Populer: Sain Politik Hukum Sosial Budaya (Surabaya: Pustaka Gema Press, 2016).

${ }^{41}$ Ernawati, "Konsep Pendidikan Rumah Tangga dalam Perspektif Cahyadi Takariawan," Syamil: Jurnal Pendidikan Agama Islam 3, no. 1 (2015): 106.
The explanation above also illustrates the importance of preaching Tabligh to always provide understanding to pilgrims or audiences. Da'wah tabligh that is intense only applies to compulsory worship such as Friday's khubat, obligatory worship for Christians on Sundays and Hindus. But this tabligh perspective propaganda does not apply on ordinary days as explained above that there is nothing scheduled regarding the meeting between the figures preaching tabligh outside worship obligatory unless there is a meeting at the event such as majelis taklim, grief, worship columns and etc. The results of the above interviews of each character also illustrates that there is already awareness of religious leaders to always enlighten their worshipers to always maintain harmony among fellow human beings, because religious leaders understand this has indeed become their obligation to preach even without being told any more.

\section{Worship Tolerance}

We as Indonesian people are often proud or proud as a nation of high tolerance and harmony between religions. Because religious tolerance religious harmony is created in harmony between religious adherents through awareness of tolerance and mutual cooperation between each other. ${ }^{43}$ The expressions from the informants that they illustrate, there is a very high tolerance value found in Mopuya Selatan Village. Tolerance in terms of worship will not interfere with the beliefs of the followers of other religions, this is done so that there can be a very harmonious relationship between the people without being disturbed by each other

${ }^{42}$ H. Imam Sujai, S.Ag, S.Pd, as Tokoh Agama Umat Islam, interviewed on 17th April 2019, Barent Suahani, S.TP, as Tokoh Agama Umat Kristen, interviewed on 18 $8^{\text {th }}$ April 2019 dan I Wayan Sutaman, SP, as Tokoh Agama Umat Hindu, interviewed on $19^{\text {th }}$ April 2019

43 Kunawi Basyir, "Pola Kerukunan Antarumat Islam dan Hindu di Denpasar Bali," Islamica: Jurnal Studi Keislaman 8, no. 1 (2013): 5. 
when the time of worship comes. By promoting the principle of high and good tolerance it does not mean that we as religious people are free to participate in other worship that is not in accordance with our creeds or beliefs, but high tolerance and good here gives an understanding to be able to understand each other from the aspect of worship so that conflict does not occur only with reason there is no question of mutual understanding from fellow religious communities. $^{44}$

\section{Challenges and Solutions of Community Leaders in Overcoming Conflicts in Plural Societies}

Efforts to manage the plurality of the people of Mopuya Selatan Village need to be an appropriate propaganda approach that must be carried out by religious leaders to be able to provide good teaching to each congregation and preaching must be done in accordance with the conditions and conditions of the people of Mopuya Selatan Village itself. Therefore the need for in-depth analysis and understanding related to the needs needed by the community in terms of religion. With the plurality of the community, it certainly requires an appropriate propaganda strategy or approach. But on the journey of preaching we are sometimes hindered or find a challenge where this challenge which slows down can even have a negative effect on harmony among religious communities that have existed for a long time.

Long-standing harmony in the people of Mopuya Selatan Village does not mean that there are no challenges or threats that occurred. These challenges usually occur because of internal and external factors in the community of Mopuya Selatan Village itself. Despite facing challenges as a government and religious leader, they must be able to provide solutions to the

${ }^{44}$ H. Imam Sujai, (Leader of Hindu) Interview, \{Wednesday, 17 th April 2019\}; Barent Suahani, (Leader of Christ) Interview, \{Thursday, 18 th April 2019\}; and I Wayan Sutaman, (Leader of Hindu) Interview, \{Friday, 19 th Apil 2019\} diseases that occur so that harmony will continue to exist until the end of this world. All elements must think and act to find the root of the problem and provide a solution. One solution to overcome the problem is to promote multicultural education for the next generation. $^{45}$

\section{Educational Factors}

Education can be understood by us that education is a means to educate and can provide more insight to students. Most people understand that education only lies in formal institutions such as schools and universities. More broadly we understand that there are three characteristics of education, which are informal, non-formal and formal. Informal education is education obtained or implemented by the family environment, Non-formal education is education that is extracurricular in nature such as landfill, place of courses and so on, and formal education, namely public or private official schools. The lack of awareness of our predecessors related to the importance of education resulted in the occurrence of knowledge auctions and understanding and difficulty in digesting scientific information. This is one of the obstacles of religious leaders to provide understanding to the community.

The expression of the informant that he says, the challenges that must be faced by religious leaders in delivering da'wah namely that the lack of awareness of our parents towards education causes difficulty in absorbing the material presented. Unequal level of education causes religious leaders to be confused in presenting the material to be presented. When giving an understanding to an educated community it is certainly easy, but on the contrary if this da'wab is delivered to the public

45 Rahmania Sadek, "Pendidikan Multikultural dalam Masyarakat Majemuk," Dodoto: Jurnal Pendidikan 17, no. 17 (2019): 23. 
who have never received an education, of course this is one of the obstacles for the nonconveyance of the material to be presented. ${ }^{46}$

The challenges discussed from the explanation above are also discussed in communities that do not have adequate levels of education. Based on the data sources above the number of tabulations for the level of education, especially the population who graduated from elementary school is more dominant compared to the level of education above. Unlike the case when religious leaders provide understanding to educated people. Actually this level of education has the potential to be related to whether or not the da'wah is carried out successfully by religious leaders.

\section{Political Factors}

Political science is about the relationship between humans and one another in the form of appreciation, understanding, until the arrangement regarding matters of obtaining, maintaining, and exercising power in social life, both arising from human desires individually in group life, and arising from the process of interaction within the community or organized unity. So matters relating to politics include three main elements, there are power, authority and order. ${ }^{47}$

The political system can be interpreted as a unity that forms from several elements or components. The elements of each component are interconnected structurally and functionally, there is an attachment in achieving the main goals of each cohesive so that its existence is always intact and its totality is maintained. ${ }^{48} \mathrm{But}$ it is different with Mopuya Selatan Village which has a plural population.

46 H. Imam Sujai, (Tokoh Agama Umat Islam) Interview, $\left\{17^{\text {th }}\right.$ April 2019$\}$

47 Teuku May Rudy, Pengantar Ilmu Politik: W awasan Pemikiran dan Kegunaannya, Cet VI (Bandung: Refika Aditama, 2013), p. 21.
The interview results revealed by several informants showed that when the political years had entered, political actors were involved then they tend to justify all means to achieve their interests. With the existence of irresponsible politicians who will eventually become victims in the community itself because it has been provoked by issues that are beneficial to some groups for the benefit of the group itself. With good awareness from the government, religious leaders, and the community can certainly minimize the conflicts that will occur caused by the politicians themselves. Long-standing awareness and harmony and the presence of good social factors from the community can certainly help reduce the nature of fanaticism itself although we cannot deny there are some elements who still want to ignite all means for their interests. ${ }^{49}$

The various challenges above, of course the need for a solution to provide a unifying drug for the people to remain harmonious and peaceful as what our beloved nation aspires.

\section{Persuasive Approach}

Persuasive is a heart-to-heart approach or an approach that is good or non-violent. Likewise what community leaders did everything in the village of Mopuya Selatan, the approach taken to provide understanding to the community is through a persuasive approach. The statement of the informant above illustrates that an effective approach that must be taken by religious leaders is by a persuasive approach, because this approach is the most efficient way when we provide understanding to people who are less educated, in other words this approach is a way to attract sympathy from the person we want to preach. With this

\footnotetext{
48 Sahya Anggara, Sistem Politik Indonesia (Bandung: CV Pustaka Setia, 2013), p. 12.

${ }^{49}$ Kuswandi Gali, (Kepala Desa Mopuya Selatan) Interview, \{16 ${ }^{\text {th }}$ April 2019); I Wayan Sutaman, (Tokoh Agama Umat Hindu) Interview, \{19 th April 2019\}; Indra Wardana $\{$ Masyarakat $)$ Interview $\left\{20^{\text {th }}\right.$ April 2019$\}$
} 
approach, when we have established a good emotional relationship, what we say will be easily accepted by the community. Other words from persuasive also have soft meaning, this approach is a dynamic approach to the existing social reality. ${ }^{50}$

\section{Language Equality}

Efforts in Equality in language that are carried out are attempts to provide understanding to the people who want to be indicted, this effort as carried out by religious leaders in Mopuya Selatan Village. The results of the interview above provide an understanding that with language adjustments, what is conveyed is easily accepted by the audience. Religious leaders certainly must have knowledge and understand the situation and the condition of the community in the sense that when preaching we must be able to adjust to the language of the community so that what is conveyed can be digested and accepted by the community itself.

Even though what we have said is good, but when it is not understood by the people who are the target of da'wah then what is conveyed will be in vain because they are unable to change the behavior of the people themselves. Mopuya Selatan Village as described above is a very plural area of religion, ethnicity, culture and language, but the majority of the people of Mopuya Selatan Village are trans migrants from Java Island, so many people use Javanese, but in the village the wider plain of North Sulawesi has a unifying language that we know as market language. ${ }^{51}$

Explanation of the informants above emphasizes the use of everyday language because the people of Mopuya Village, especially for our parents, do not have a lot of education. So that what we convey can be easily digested and understood the need for language adjustments, because in effective communication to formulate da'wah strategies one of which is by adjusting the language. This language adjustment is not the people who have to follow the language of the mubaligh but the mubaligh who must adjust to the language.

\section{Conclusion}

Based on the results of field research conducted by researchers that the community of Mopuya Selatan Village is a plural society. Plurality can be seen by the existence of several places of worship, the existence of several cultures and languages. The existence of plurality it is necessary to have a strategy of religious leaders to always do to provide understanding to the community to avoid conflicts related to sara. Associated with aspects of plurality, the strategies implemented by religious leaders in avoiding conflict are by assimilating activities and tolerating muamalah worship. The nature of the family and social values that have been well established are the existence of similarities and interdependence in terms of work.

There are disputes of understanding and interests that hamper the role of religious leaders to provide understanding to the community, of course there is an approach to overcoming all of that is with a persuasive approach with the aim of establishing good emotional relations between figures and the community, so that what is conveyed can be implemented in social life. In the results of the above research, it is indeed necessary that the role of religious leaders be to answer all problems that occur in the community. Namely always increase the sense of kinship to the community by involving one another in things that are social without group discrimination. Give patience to the community with work that aims to meet economic needs, so
${ }^{50}$ H. Imam Sujai, (Tokoh Agama Umat Islam) Interview, $\left\{17^{\text {th }}\right.$ April 2019\}
${ }^{51}$ Kuswandi Gali, (Kepala Desa Mopuya Selatan) Interview, $\left\{16^{\text {th }}\right.$ April 2019\} 
that people focus on work not on problems that are not productive.

\section{References}

Book

Anggara, Sahya. Sistem Politik Indonesia. Bandung: CV Pustaka Setia, 2013.

Azra, Azzumardi. Pendidikan Islam Tradisi dan Modernisasi Menuju Milenium Baru. Jakarta: Wacana Ilmu, 1999.

Dermawan, Hamdan Daulay dan Andy. Dakwah di Tengah Persoalan Budaya dan Politik. Yogyakarta: LESFI, 2001.

Effendi, Usman. Asas Manajemen. Jakarta: Rajawali Press, 2014.

Hartati, Ismail Nurdin dan Sri. Metodologi Penelitian Sosial. Surabaya: Media Sahabat Cendekia, 2019.

Hotman, A. Ilyas Ismail dan Prio. Filsafat Dakwah, Rekayasa Menbangun Agama dan Peradaban Islam. Jakarta: Kencana Prenada Media, 2011.

Ilahi, M. Munir dan Wahyu. Manajemen Dakwah. Jakarta: Kencana Prenada Media, 2006.

Kahmad, Dadang. Sosiologi Agama. Bandung: Remaja Rosdakarya, 2000.

Martono, Nanang. Sosiologi Perubahan Sosial. Depok: RajaGrafindo Persada, 2011.

Mulkhan, Abdul Munir. Teologi Kiri, Landasan Gerakan Membela Kaum Mustadiatin. Yogyakarta: Kreasi Wacana, 2002.

Novita, Windy. Kamus Ilmiah Populer: Sain Politik Hukum Sosial Budaya. Surabaya: Pustaka Gema Press, 2016.

Nusi, Arfan. Mengaji Pluralisme Agama Kepada Nurcholish Madjid. Yogyakarta: Atap Buku, 2015.

Rudy, Teuku May. Pengantar Ilmu Politik: Wawasan Pemikiran dan Kegunaannya. Cet VI. Bandung: Refika Aditama, 2013.

Siyoto, Sandu, and M. Ali Sodik. Dasar Metedologi Penelitian. Dasar Metedologi Penelitian, 2018.

Wahyu, Ramdani. Ilmu Sosial Dasar. Bandung: CV. Pustaka Setia, 2017.
Zaenuri, Ahmad. Mengawal Peradaban (Sebuah Pemikiran Seputar Pluralisme, Pendidikan, Sosial, dan Budaya). Yogyakarta: Trussmedia Grafika, 2015.

\section{Journal}

Arifina, Anisa Setya. "Literasi Media Sebagai Manajemen Konflik Keagamaan di Indonesia." Jurnal Komunikasi dan Kajian Media 1, no. 1 (2017): 54. https://doi.org/http://dx.doi.org/10.310 02/jkkm.v1i1.390.

Bahari, Yohanes. "Model Komunikasi Lintas Budaya dalam Meresolusi Konflik Berbasis Pranata Adat Melayu dan Madura di Kalimantan Barat." Jurnal Ilmu Komunikasi 6, no. 1 (2008): 1-12. https://doi.org/https://doi.org/10.3131 5/jik.v6i1.41.

Basyir, Kunawi. "Pola Kerukunan Antarumat Islam dan Hindu di Denpasar Bali." Islamica: Jurnal Studi Keislaman 8, no. 1 (2013): https://doi.org/https://doi.org/10.1564 2/islamica.2013.8.1.1-27.

Ernawati. "Konsep Pendidikan Rumah Tangga dalam Perspektif Cahyadi Takariawan." Syamil: Jurnal Pendidikan Agama Islam 3, no. $1 \quad$ (2015): 106. https://doi.org/https://doi.org/10.2109 3/sy.v3i1.240.

Hanik, Umi. "Pluralisme Agama di Indonesia." Tribakti: Jurnal Pemikiran Keislaman 25, no. $1 \quad$ (2014): 61 https://doi.org/https://doi.org/10.3336 7/tribakti.v25i1.154.

Hardiyanti, Sitti, and Idham Irwansyah. "Faktor-Faktor Yang Mempengaruhi Penggunaan Kontrasepsi dan Hak Reproduksi Perempuan pada Keluarga Akseptor KB di Kelurahan Maccorawalie Kab. Pinrang." Predestination: Journal of Society and Culture 1, no. 2 (2021): 97. https://doi.org/https://doi.org/10.2685 8/prd.v1i2.17951.

Jannah, Hasanatul. "Kyai, Perubahan Sosial dan Dinamika Politik Kekuasaan." Fikrah Jurnal Ilmu Aqidah dan Studi Keagamaan 3, no. 1 (2015): 173. 
https://doi.org/10.21043/fikrah.v3i1.183 1.

Jati, Wasisto Raharjo. "Kearifan Lokal Sebagai

Resulosi Konflik Keagamaan." Jurnal $W$ alisongo 21, no. 2 (2013): 393-416. https://doi.org/https://doi.org/10.2158 0/ws.21.2.251.

Kholifah, Yusnia Binti. "Manajemen Konflik Perspektif Pendidikan Islam." Piwulang: Jurnal Pendidikan Agama Islam 2, no. 1 (2019):

https://doi.org/http://dx.doi.org/10.324 78/piwulang.v2i1.298.

Kodina, Yohana Elce, Bahaking Rama, Abd. Rahman Getteng, and Nurman Said. "Hakikat Materi Akidah Perspektif Pendidikan Agama Islam dalam Kurikulum Sekolah Dasar Kelas V.” Jurnal Diskursus Islam 4, no. 3 (2016): 525. https://doi.org/https://doi.org/10.2425 2/jdi.v4i3.7399.

Marwantika, Asna Istya. "Pemetaan Aliran Pemikiran Dakwah Ditinjau dari Periodisasi Gerakan Dakwah dan Konsep Keilmuan." Qalamuna: Jurnal Pendidikan, Sosial dan Agama 7, no. 1 (2015): 5. https://doi.org/https://doi.org/10.3768 0/qalamuna.v7i01.364.

Moh. Shofan. "Pluralisme Agama Bukan Nihilisme: Respon untuk Kaum Fundamentalis." Konfrontasi: Jurnal Kultural, Ekonomi dan Perubahan Sosial 3, no. 1 (2016):

https://doi.org/https://doi.org/10.3325

8/konfrontasi2.v1i1.83.

Muliati, Indah. "Manajemen Konflik dalam Pendidikan Menurut Perspektif Islam." Tingkap: Jurnal Ilmiah Ilmu-Imu Sosial Budaya \& Ekonomi 12, no. 1 (2016): 50. http://ejournal.unp.ac.id/index.php/ting $\mathrm{kap} /$ article/view/7448/5838.

Ramadhan, Iwan, Agus Sastrawan Noor, and Supriadi. "Asimilasi Perkawinan ArabMelayu Kampung Arab Kelurahan dalam Bugis Pontianak." Khatulistiwa: Jurnal Pendidikan dan Pembelajaran 4, no. 4 (2015): 2. https://doi.org/https://jurnal.untan.ac.id /index.php/jpdpb/article/view/9973.

Risman, Hendrik. “Upaya Pemerintah Daerah Kabupaten Kutai Barat dalam Menyelesaikan Konflik Tapal Batas Antar Kampung di Daerah Kabupaten Kutai Barat (Konflik Kampung Muhur dan Kampung Kaliq)." EJournal Pemerintahan Integratif 3, no. 3 (2015): 393. http:/ / ejournal.pin.or.id/site/?p=972.

Sadek, Rahmania. "Pendidikan Multikultural dalam Masyarakat Majemuk." Dodoto: Jurnal Pendidikan 17, no. 17 (2019): 23. https://doi.org/http://www.jurnal.umm u.ac.id/index.php/dodoto/article/view/3 33.

Setyarsih, Esty. "Fenomena Makelar Kost dalam Sudut Pandang Sosio Ekonomi Ditinjau dari Teori Pertukaran Peter Michael Blau." Jurnal Analisa Sosiologi 6, no. $2 \quad$ (2017): 86. https://doi.org/https://doi.org/10.2096 1/jas.v6i2.18192.

Valentina Purnama Dewi, Sugeng Suwagi, Udin Sumarsah, Sofyan Sauri, Faiz Karim Fatkhulah. "Penerapan Manajemen Konflik Berbasis Agama dan Psikologi Studi Kasus di SMK Negeri 29 Jakarta." Eduvis: Jurnal Manajemen Pendidikan Islam 6, no. 2 (2021): 127. http://journal.bungabangsacirebon.ac.id/ index.php/eduvis/article/view/386.

Waduloh, Hasan. "Manajemen Konflik dalam Perspektif Dakwah." Jurnal Dakwah Tabligh 15, no. 1 (2014): 103. https://doi.org/https://doi.org/10.2425 2/jdt.v15i1.340.

Wahyuni, Ida Windi. "Penerapan Nilai-Nilai Moral Pada Santri TPQ Al-Khumaier Pekanbaru." Generasi Emas:Jurnal Pendidikan Islam Anak Usia Dini 1, no. 1 (2018): https://doi.org/https://doi.org/10.2529 9/ge.2018.vol1(1).2256.

Wiradaningrat, Hamdani Khaerul Fikri dan Danu. "Strategi dan Solusi Dakwah pada Masyarakat Multikultural." Mudabbir: Jurnal Manajemen Dakwah 1, no. 2 (2020): 143-44. https://doi.org/https://journal.uinmatar 
am.ac.id/index.php/mudabbir/article/vie $\mathrm{w} / 3165$.

\section{Thesis and Disertation}

Thaib, Erwin Jusuf. "Dakwah dalam Perspektif Pluralitas (Studi Analis SWOT Pada Masyarakat Kota Gorontalo)." UIN Alauddin Makassar, 2016. http://repositori.uinalauddin.ac.id/298/1/Erwin Jusuf Thaib.pdf.

\section{Articles in Newspapers and Magazines}

Pimpinan Pusat Muhammadiyah. Berita Resmi Mubammadiyah. Gramasurya, 2015.

\section{Interview}

Agus Suwito, (community) Interview, \{Sunday, $21^{\text {th }}$ April 2019\}

Barent Suahani, (Leader of Christ) Interview, $\left\{\right.$ Thursday, $18^{\text {th }}$ April 2019\}

Indra Wardana, (Community) Interview, \{Saturday, $20^{\text {th }}$ April 2019\}

I Wayan Sutaman, (Leader of Hindu) Interview, \{Friday, $19^{\text {th }}$ Apil 2019\}

H. Imam Sujai, (Leader of Hindu) Interview, $\left\{\right.$ Wednesday, $17^{\text {th }}$ April 2019\}

Kuswandi Gali, (Village Head of Mopuya Selatan Village) Interview, \{Tuesday, $16^{\text {th }}$ April 2019\} 